\title{
MEDICAL REHABILITATION SYSTEM AND ITS QUALITY CONTROL IN DEVELOPED COUNTRIES OF THE WORLD
}

D0I: 10.36740/WLek202009227

\author{
Viktor I. Shevchuk, Oksana B. Yavorovenko, Natalia M. Belyaeva, Iryna V. Kurylenko \\ RESEARCH INSTITUTE OF REHABILITATION (MEDICAL SCIENTIFIC TRAINING (ENTER) OF VINNYTSIA NATIONAL PIROGOV MEMORIAL MEDICAL \\ UNIVERSITY, VINNYTSIA, UKRAINE
}

\begin{abstract}
The aim: To review scientific literature dealing with evaluation of medical rehabilitation effectiveness and quality in the world. Materials and methods: Review and generalization of scientific literature on the criteria of evaluation of medical rehabilitation quality in advanced industrialized societies. Conclusions: Despite differences in the structure of medical rehabilitation in world societies, the end point is similar - assessment of quality of life of a sick person, measured by various criteria and standards. This experience is of great value for the development of national system of rehabilitation services.
\end{abstract}

KEY WORDS: medical rehabilitation, assessment of quality, patients

Wiad Lek. 2020;73(9 p. II):2040-2043

\section{INTRODUCTION}

In market economy conditions, one of the most important tasks of public health and social protection authorities is to ensure a sufficient quality of life for socially disadvantaged groups of population [1]. Adequate functional status of disabled, elderly, and sick individuals can be achieved by comprehensive rehabilitation therapy, consisting of medical, social, and professional aspects. The most important component of rehabilitation care, determining the effectiveness of rehabilitation in general, is medical rehabilitation [2]. Therapeutic measures carried out within the program of medical rehabilitation of disabled and sick individuals are part of the system of medical and preventive care, which can be controlled using rich experience of national healthcare system [3-7]. Unfortunately, public health authorities do not focus on the assessment and quality control of medical rehabilitation in disabled and sick persons. The lack of technological and medico-economic standards for assessing the quality of rehabilitation care for sick and disabled individuals makes it impossible to use unified approaches to rehabilitation therapy in medical institutions of different forms of property, as well as hierarchical relationship between its stages.

\section{THE AIM}

To present the review of scientific literature dealing with evaluation of medical rehabilitation effectiveness and quality in the world.

\section{MATERIALS AND METHODS}

Review and generalization of scientific literature on the criteria of medical rehabilitation quality assessment in advanced industrialized societies.

\section{REVIEW AND DISCUSSION}

In recent decades, many countries around the world have been developing the system of medical rehabilitation aimed at restoration of functional ability and quality of life to those with physical impairments, as well as their maximal integration or reintegration in society and prevention of disability [8-12]. It should be noted that each country arranges the system of medical rehabilitation according to its national requirements.

For example, in Germany rehabilitation therapy is carried out at the in-patient and outpatient medical institutions and the so-called day-care clinics $[12,13]$. In-patient institutions include rehabilitation centers, rehabilitation departments at large hospitals, sanatoria and resort centers. But outpatient treatment is preferred if possible. Such forms of rehabilitation services as day-care facilities and hospitals for patients with chronic diseases and disabled individuals who do not require continuous all-day medical supervision are also common. To determine the rehabilitation efficiency, the method of questioning patients at discharge from the rehabilitation center is used [14]. Currently, rehabilitation standards are being developed to analyze and guarantee the quality of therapy course. Public health service is based on well-structured health insurance system consisting of compulsory state insurance (CSI) and private health insurance funds.

In France, much of inpatient rehabilitation measures are carried out as concomitant restorative therapy during the patient's stay in the hospital. In-patient treatment is commonly divided into categories depending on duration of treatment: curteduree, or short-term treatment for acute condition; moyenneduree, or medium duration treatment, implying rehabilitation or health-improving therapy; longueduree, or long-term treatment in centers for disabled [15]. Sometimes rehabilitation 
in France is determined as "moyensejour", or treatment of medium duration. In French rehabilitation centers, the quality management process has not been elaborated in details due to structural peculiarities of clinics. A rehabilitation center can receive the permission to treat patients if it fulfills certain standard requirements, e.g. training room equipment, the presence of at least one swimming pool, balneotherapy and physiotherapy rooms, including a place for loop tables, electrotherapy apparatuses, rooms for ergotherapy, gypsum rooms, rooms for training devices, rooms for language training, halls and classes for school, professional and social reintegration, leisure facilities [12].

Currently, public consultations are in progress as to medical rehabilitation significance, having focused on funding shortage of rehabilitation centers and clinics [16]. Financing of private clinics, being fixed by the district prefect, is insufficient as well. But low funding for rehabilitation services is associated with decreased therapeutic potential, and treatment itself is limited to nursing process and is not aimed at reintegration of patients.

Cost-effectiveness of many clinics is not guaranteed, since health insurance providers financing rehabilitation programs, contemplate to minimize co-payment, making medical rehabilitation practically inaccessible because of initially high cost of treatment. Public consultations on the development of rehabilitation service system in France address the problems of giving longitudinal attention to disabled individuals, as health insurance system does not provide proper care for such patients, as in Germany. Because of insufficient number of affordable skilled nursing facilities, rehabilitation departments are overcrowded with disabled patients, and therefore cannot be used as intended. The only financing structure for medical rehabilitation service in France is medical care insurance. It is a part of general social insurance system and covers about $80 \%$ of population [17].

In Switzerland, hospitals have a multidisciplinary principle of treatment being staffed with appropriate specialists [18]. Rehabilitation treatment plan of each hospitalized patient is extended and subdivided into weekly plans, the goals of rehabilitation are determined. Doctors are responsible for further diagnostics, administrations, coordination and control of therapeutic measures in accordance with rehabilitation plan, institution of special forms of treatment, keeping clinical recording, making further recommendations for rehabilitation after discharge of the patient and writing hospital discharge list with epicrisis, which is sent to the family doctor and financing organization. Hospital discharge epicrisis has no a unified structure; instructions concerning working capacity of patients are given as needed. In Swiss medical rehabilitation system, the concept of quality management is incorporated into the Health Insurance Act. Certain criteria, associated with staffing level, are crucial in determining the potential capabilities of rehabilitation clinic to perform rehabilitation therapy. For example, the number of physical therapists should provide at least 2.5 hour sessions per patient per day, otherwise quality of treatment is considered to be poor. Besides, the level of professional competence confirmed by relevant certificates, is checked. The following minimal staff should be provided at $90 \%$ load of beds: 0.05 doctors, 0.2 nurses, 0.2 physical therapists per bed. Nongovernmental organization "Agency in Promotion of Evaluation and Quality" (APEQ) establishes a set of quality criteria and monitors rehabilitation clinics in accordance with ISO 9001 standards [19]. According to those criteria and standards, health care providers can obtain internationally acceptable certificates for quality management systems. Medical rehabilitation services are funded by state insurance institutions.

In Spain, rehabilitation therapy system at in patient specialized rehabilitation clinics is generally underdeveloped, as evidenced by the level of availability of rehabilitation facilities - about 0.05 rehabilitation beds per 1000 population [12]. There are only 24 rehabilitation centers for 1952 beds in the country. Most of rehabilitation centers are private. In general, inpatient health care coverage is lower than in other European countries. Sanatorium and resort care in Spain does not belong to generally accessible sector of national public health system being excluded from the list of paid health care services. Public health care system is financed by tax-payers. Medical rehabilitation in Spain is a part of primary outpatient care financed by tax-payers and is carried out on an outpatient basis in primary care centers [20]. There are about 2500 such centers where every citizen can get diagnostic, therapeutic, preventive and rehabilitation services.

In the United Kingdom, medical rehabilitation as well as rehabilitation in general is placed between two separate systems: National Health Service (NHS) on the one hand, and Social Security System on the other [21]. Such intermediate position creates some difficulties for assuring medical, professional and social rehabilitation services. The problem is delineation of responsibilities between National Health Service and Social Security System. In the UK, medical rehabilitation therapy is usually carried out as part of inpatient treatment. The outpatient care is provided by qualified district and community nurses responsible for home health service of patients in need. Rules and regulations concerning quality management control are rarely included in the budget agreement between municipal health care districts and hospitals and are commonly solved internally. The control of medical activity is regulated in personnel of the hospital by means of command-and-control structure headed by director general. The so-called clinical audit is commonly used. When purchasing medical services for their patients, family doctors are responsible for quality of outpatient and inpatient therapy. The financing is provided by state budget at taxpayers' expense.

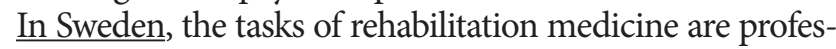
sional reintegration, vocational education, employment assistance, arranging adequate living conditions after discharge from the hospital, in addition to further diagnosis and in patient treatment, establishing a connection with social services, agencies for labor and health insurance providers if necessary [22]. Physical and rehabilitation medicine experts are responsible for physiotherapy and ergotherapy procedures, provide advice to those referred by family doctors or agencies for labor. Having deep knowledge of psychology, logopedics and social medicine, they are guided by principles of urgency medicine measures. Primary health care is usually provided in medical centers of provinces consisting of hospitals and 
outpatient clinics [23]. According to the guidelines of the Ministry of Health and Social Affairs, each patient has the right for individual rehabilitation plan [24]. Assurance of quality in rehabilitation departments is controlled by the Swedish Society of Rehabilitation Medicine, which issues quality certificates. In accordance with Regulations on quality management in health care, all funding public health bodies are obliged to participate regularly in quality control monitoring. Each hospital is obliged to develop its own quality control system. Quality control registers have been made for self-monitoring of health care vendors as well as governmental quality control. Currently, chronic pathology is one of the major problems under discussion in the country. About $45 \%$ of individuals with chronic diseases are disabled for more than twelve months. Early disability retirement is unprofitable for retirement insurance system because of redistribution of financial expenditures but not problem solution. Medical rehabilitation is of great importance for public health in Sweden implying prevention of early disability in many cases. In Sweden, public health is 95\% state-funded.

In the USA, rehabilitation centers are part of scientific and medical associations [25]. They are 30 multidisciplinary medical centers outfitted with state-of-the-art equipment. Inpatient rehabilitation therapy consists primarily of early rehabilitation carried out in rehabilitation departments of large hospitals [23]. Outpatient medical service is nursing care providing home rehabilitation services. To make a contract with the so-called Health Maintenance Organizations (HMOs), healthcare centers are to report on quality and effectiveness of their work. Functional Independence Measure (FIM) has become widely used, serving as a tool for statistical comparison of rehabilitation outcomes between rehabilitation institutions [26]. Hospitals in the United States are subjected to strict quality control and are obliged to verify accreditation every 3 years in order to prolong the right for providing medical services to people. In this way the state control and impact on the health care system are exercised.

Most of above mentioned peculiarities in the US health care and rehabilitation system are rather specific and cannot be transferred to other countries. At the same time, certain economic aspects are taken as a model in other countries including Europe. Thus, a prospective payment system on the basis of diagnosis related groups (DRG) was introduced in 2004 in Germany [27]. Similar to many other countries where DRGs are in use such as the USA and Australia, one of the major goals for implementation of this hospital reimbursement system has been reducing health care expenditures and cost control by setting hospitalization payment for all payers at a fixed DRGrate per admission. Hospitals have an interest in rapid transfer of patients to early rehabilitation, eventually leading to positive impact on both rehabilitation and treatment outcomes. In the USA there is a need in arrangement of early rehabilitation departments as well as further development of practical rehabilitology as a whole. The US system of inpatient treatment financing on the whole, and rehabilitation treatment (inpatient or outpatient) in particular, is multidimensional being represented by a large number of public or private insurance options.

In Finland, the Ministry of Social Affairs and Health is the body responsible for implementation of laws in the field of rehabilitation for disabled individuals. The coordination of actions between various sectors of health care system in this field is performed by National Coordination Committee on Rehabilitation, National Rehabilitation Council, municipal councils and cooperation groups in provinces. Medical rehabilitation can be provided either in a rehabilitation center or as outpatient therapy allowing the patient to live at home [28]. In addition, rehabilitation at sole discretion and psychotherapy rehabilitation are available. In Finland, continuity in therapy stages is practiced, thereby improving the quality of rehabilitation and shortening its time [29]. According to the National Pensions Act, medical rehabilitation in Finland is financed by the Social Insurance Institution of Finland. Insured individuals receive rehabilitation therapy in accordance with the Rehabilitation Services Act [30].

\section{CONCLUSIONS}

Despite considerable differences in organization of medical rehabilitation in industrialized countries, methodological approaches are similar in terms of basic purposes and methodical principles of rehabilitation medicine.

It is the assessment of quality of life of disabled individuals that determines the effectiveness of rehabilitation therapy in many countries of the world. Rehabilitation success is measured by instruments that assess performance of activities of daily living. To assess final functional status of patients after rehabilitation therapy, and thus its effectiveness, objective and subjective factors are considered: questionnaires, equipment of rehabilitation departments, adequacy of the staff, competence level of hospital staff, interdepartmental control, quality control registers. Functional independence measure (FIM) is a widely accepted functional assessment measure used during inpatient rehabilitation in many countries. Besides, administration of stage-to-stage treatment leads to minimization of negative effects and improvement of rehabilitation quality.

International experience in functioning of medical rehabilitation systems in industrialized countries as well as means of their quality assessment, presented in the review, can serve a valuable example for Ukrainian health care experts in the development of effective national system of rehabilitation medicine.

\section{REFERENCES}

1. Stojka A. Zarubizhnij dosvid organizaciyi obslugovuvannya socialnonezahishenih verstv naselennya. Derzhavne upravlinnya ta misceve samovryaduvannya. 2009: 191-200. (in Ukrainian).

2. Stucki G., Bickenbach J., Melvin J. Strengthening Rehabilitation in Health Systems Worldwide by Integrating Information on Functioning in National Health Information Systems. Am J Phys Med Rehabil. 2017; 96(9): 677-681.

3. Shevchuk V.I., Belyayeva N.M., Yavorovenko O.B., Kurilenko I.V. Suchasnij stan mediko-socialnoyi reabilitaciyi invalidiv v Ukrayini. Zdorov'ya lyudini: teoriya i praktika: materiali konferencii. Za zag. red. 0.0. Yezhovoyi. Sumi: Sumskij derzhavnij universitet, 2017: 29-36. (in Ukrainian). 
4. Ipatov A.V. Derzhavne regulyuvannya mediko-socialnih problem invalidiv: zarubizhnij dosvid dlya Ukrayini. Derzhava i regioni : Derzhavne upravlinnya. 2010; 2: 121-123. (in Ukrainian).

5. Babov K.D., Zolotarova T.A.Vprovadzhennya naukovih zdobutkiv u galuzi medichnoyi reabilitaciyi v reformu ohoroni zdorov'ya. Naukovij zhurnal MOZ Ukrayini. 2012; 1(1): 126-131. (in Ukrainian).

6. Berlinec I.A. Zarubizhnij dosvid u sferi medichnoyi reabilitaciyi: perspektivi vikoristannya v Ukrayini. Derzhavne upravlinnya: udoskonalennya ta rozvitok. 2019; 4. (in Ukrainian).

7. Halytskyi 0., Gryshova R. Cvitovij dosvid realizaciyi derzhavnoyi politiki pidtrimki osib z invalidnistyu ta jogo implementaciya v Ukrayini. Investiciyi: praktika ta dosvid. 2019; 6: 122-127. (in Ukrainian).

8. Benzer W., Rauch B., Schmid J.P. et al. Exercise-based cardiac rehabilitation in twelve European countries results of the European cardiac rehabilitation registry. Int J Cardiol. 2017; 1; 228: 58-67.

9. Prodinger B., Ndosi M., Nordenskiöld U. et al. Rehabilitation provided to patients with rheumatoid arthritis: a comparison of three different rheumatology clinics in Austria, Sweden and the UK from the perspectives of patients and health professionals. J Rehabil Med. 2015; 47(2): 174-182.

10. Vlak T., Moslavac S. Physical and rehabilitation medicine practice in offices of general practitioners and family doctors in Croatia: controversies and resolution. Eur J Phys Rehabil Med. 2018; 54(1): 121-122.

11. Smychok V.B., Leschinskaya T.M., Kopytok A.V. et al. Organizaciya medicinskoj reabilitacii pacientov v Respublike Belarus. Medicinskie novosti. 2012; 11: 36-41. (in Russian).

12. Yunusov F.A., Gajger G., Mikus E., Manuvald 0. Organizaciya medikosocialnoj reabilitacii za rubezhom. M., 00F Socialnoe razvitie Rossii. 2008; 332. (in Russian).

13. Reinsberg B. Rehabilitation für die Zukunft - Deutsche Vereinigung für Rehabilitation feierte ihr 100. Gründungsjubiläum im April 2009 in Berlin. Rehabilitation. 2009; 48(4): 238-239.

14. Letzel J., Angst F., Weigl M.B. Multidisciplinary biopsychosocial rehabilitation in chronic neck pain: a naturalistic prospective cohort study with intraindividual control of effects and 12-month follow-up. Eur J Phys Rehabil Med. 2018, Nov 21. doi: 10.23736/S1973-9087.18.053480.

15. Fromont A., Lehanneur M.N., Rollot F. et al. [Cost of multiple sclerosis in France]. Rev Neurol (Paris). 2014; 170(6-7): 432-439. (in French).

16. Yelnik A. Financement de l'activité en médecine physique et de réadaptation, questions en cours et perspectives. Ann Phys Rehabil Med. 2009; 52(6): 451-452.

17. Dervaux B., BaseilhacE., Fagon J.Y. et al.Évaluation médico-économique des produits de santé. Méthodologie pour la définition d'un impact significatif sur les dépenses de l'Assurance maladie et choix des référentiels pour l'interprétation des résultats. Therapie. 2014, Jul-Aug; 69(4): 323-330.

18. Simons J., Thévoz D., Piquilloud L. [Principles and challenges of mobilization in intensive care]. Soins. 2016; (806): 13-17. (in French).

19. Haizmann J.J., Kalbfuss D. [Quality management in rehabilitation centers: evaluation of an experience with two reference generations]. Rev Med Suisse Romande. 2001; 121(11): 809-10. (in French).

20. Escriche Ros R., Morata Crespo A.B. Atención primaria y rehabilitación: a propósito de la relación entre niveles asistenciales, ¿qué opinan en los centros de salud? Aten Primaria. 2012; 44(10): 628-629.

21. Graham L.A. Organization of rehabilitation services. Handb Clin Neurol. 2013; 110: 113-120.
22. Sturesson M., Edlund C., Falkdal A.H., Bernspång B. Healthcare encounters and return to work: a qualitative study on sick-listed patients' experiences. Prim Health Care Res Dev. 2014; 15(4): 464-475.

23. Ovretveit J., Ramsay P., Shortell S.M., Brommels M. Comparing and improving chronic illness primary care in Sweden and the USA. Int J Health Care Qual Assur. 2016; 29(5): 582-595.

24. Lexell E.M., Lexell J., Larsson-Lund M. The rehabilitation plan can support clients'active engagement and facilitate the process of change - experiences from people with late effects of polio participating in a rehabilitation programme. Disabil Rehabil. 2016; 38(4): 329-336.

25. Heinemann A.W. State of the science on postacute rehabilitation: setting a research agenda and developing an evidence base for practice and public policy. An introduction. Assist Technol. 2008; 20(1): 55-60.

26. Chiou-Tan F.Y., Keng M.J. Jr., Graves D.E. Racial/ethnic differences in FIM scores and length of stay for underinsured patients undergoing stroke inpatient rehabilitation. Am J Phys Med Rehabil. 2006; 85(5): 415-423.

27. Alberty J., Franz D., Leuwer R. et al. Das G-DRG-System 2004 und seine Schnittstellen zum ambulanten Sektor. Steht die HNO-Heilkunde vor einem Strukturwandel? HNO. 2004, May; 52(5): 387-393.

28. Reunanen M.A., Järvikoski A., Talvitie U. et al. Individualised home-based rehabilitation after stroke in eastern Finland - the client's perspective. Health Soc Care Community. 2016; 24(1): 77-85.

29. Pulkki J.M., Rissanen P., Raitanen J.A., Viitanen E.A. Use and distribution of rehabilitation services: a register linkage study in one hospital district area in Finland. International journal of rehabilitation research. 2011; 34(2): 160-166.

30. Laaksonen M., Gould R. Return to Work After Temporary Disability Pension in Finland. J Occup Rehabil. 2015; 25(3): 471-80.

\section{ORCID and contributionship:}

Viktor I.Shevchuk: 0000-0003-1105-4795 A, D, F

Oksana B. Yavorovenko: 0000-0001-9196-5841 D, E

Natalia M. Belyaeva: 0000-0002-0500-8082 B,D

Iryna V. Kurylenko: 0000-0001-5492-4573 B, F

\section{Conflict of interest:}

The Authors declare no conflict of interest.

\section{CORRESPONDING AUTHOR Oksana B. Yavorovenko}

Research Institute Of Rehabilitation

(Medical Scientific Training Center)

Of Vinnytsia National Pirogov

Memorial Medical University

104 Khmelnytskyi Highway, 21029 Vinnytsia, Ukraine

tel.: + 380938003890, +380984677614

e-mail: reab@ukr.net; oksanayavorovenko@gmail.com

Received: 21.10 .2019

Accepted: 30.06 .2020

A - Work concept and design, B - Data collection and analysis, C - Responsibility for statistical analysis, D-Writing the article, $\mathbf{E}$-Critical review, $\mathbf{F}$ - Final approval of the article 